\title{
Water security, metropolitan supply and climate change: some considerations concerning the Rio de Janeiro case
}

\author{
Rosa Maria Formiga-Johnsson \\ Ana Lucia Britto
}

${ }^{I}$ Associate Professor in the Department of Environmental and Sani-tary Engineering (DESMA), State University of Rio de Janeiro (UERJ), Rio de Janeiro, RJ, Brazil.

${ }^{11}$ Professor in the Postgraduate Program in Urbanism (PROURB), Federal University of Rio de Janeiro (UFRJ), Rio de Janei-ro, RJ, Brazil.

\begin{abstract}
In this article the authors assess the current level of water security of the population of the Rio de Janeiro metropolis supplied by the Guandu System. It sets out from the premise that water security is only achieved when universal access to water is ensured - that is, when water resources are available, in adequate quantity and quality, along with water services that guarantee the human right to safe drinking water. Based on previous research, a review of the literature and official documents, it was possible to adapt and apply an analytic schema to the case study in order to evaluate the level of water security. The authors conclude that there are many risks associated with the water resources, including climate stressors, but it is the performance of the water supply service that most jeopardizes the current water security of the population of the Rio de Janeiro metropolis; the availability of water resources, both current and future, is not an obstacle to universal access to water.
\end{abstract}

Keywords: Water security, drinking water supply, climate change, Guandu System, Rio de Janeiro Metropolitan Region.

São Paulo. Vol. 23, 2020

Feature Topics: Urbanization, Planning and Climate Change

DOI: http://dx.doi.org/10.1590/1809-4422asoc20190207r1vu2020L6TD 


\section{Introduction}

The Sustainable Development Goals (SDGs) agreed by the UN have identified climate change as one of the biggest current challenges, its impacts liable to hinder the capacity of countries to achieve sustainable development. A total of 17 SDGs were defined with 169 associated targets, which have been in effect since January 2016and to be attained by 2030 .

In this article, observing metropolitan environments through the principle established in the 2030 Agenda that the SDGs are integrated and indivisible, we take as a starting point SDG 6 - "Ensure availability and sustainable management of water and sanitation for all" - in association with SDG 13 -"Take urgent action to combat climate change and its impacts."

Densely urbanized areas place strong pressure on water resources by demanding large volumes of water to supply the public and production activities, at the same time as they provoke a deterioration in water quality. The intensification and spread of urbanization make the urban supply systems more vulnerable in a scenario of climate change, especially more frequent and/or more severe droughts, as has recently been observed in Brazilian metropolises (FORMIGA-JOHNSSON; LEMOS; SOUZA-FILHO, 2019; BRITTO; FORMIGA-JOHNSSON; CARNEIRO, 2016).

Projections by the National Water Agency (Agência Nacional de Águas: ANA, 2010) estimate that 77 of the country's municipal centres, concentrated in metropolitan regions and coastal areas, will account for $42 \%$ of the total Brazilian population in 2025, estimated at around 223 million people.

In this context, the article looks to observe and discuss the water security of the public supply to the Rio de Janeiro Metropolitan Region (RJMR), focusing on the Guandu Water Production System (Figure 1). This system serves $78 \%$ of the metropolitan population - or 8.3 million people - and is strongly dependent on the water diverted from the neighbouring Paraíba do Sul Basin, which in 2014 experienced its most severe drought since 1931. 
Figure 1 - The Guandu System in the context of the water supply in the Rio de Janeiro Metropolitan Region.

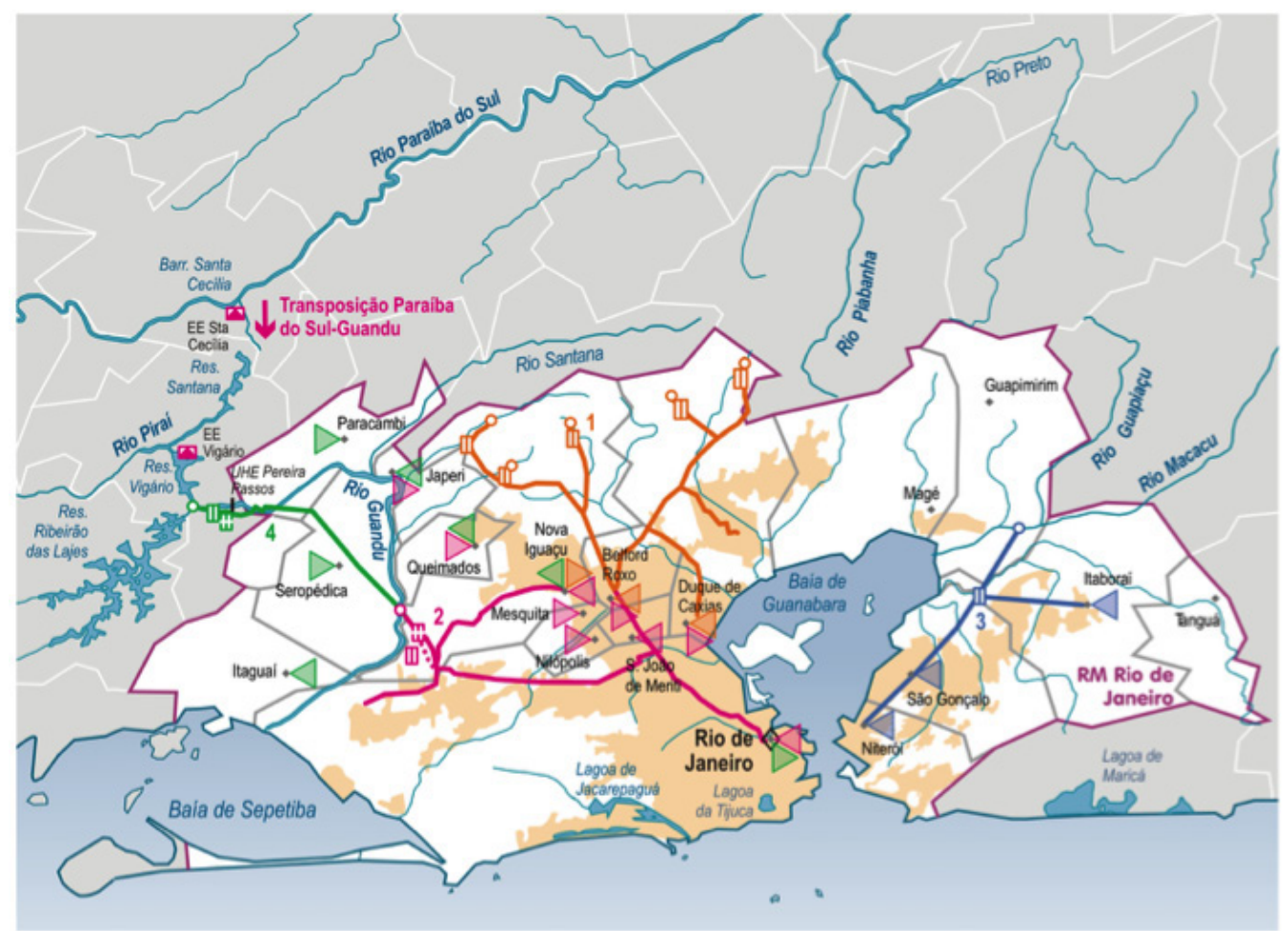

1 SIN Acari

2 SIN Guandu

3 SIN Imunana-Laranjal

4 SIN Ribeirão das Lajes

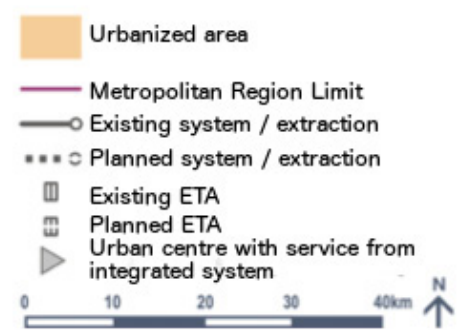

Source: ANA, 2010.

The concept of water security adopted here is broad, since it sets out from the premise that it can only be achieved when the population has universal access to safe water, as argued by Jepson et al. (2017) and Empinotti, Cortez and Ferrara (2020). In other words, the assessment of the level of global water security of the urban supply proposed here involves: i) the management of water resources, which must ensure the availability of bulk water in adequate quantity and quality for public supply; and ii) the management of the services responsible for the collection, treatment, storage and distribution of treated water for the end users, guaranteeing the human right to safe drinking water. 
To develop the proposed work, a brief review is first undertaken of the literature on water and climate change, also examining how the issue is addressed in Rio de Janeiro State's official planning documents. Next, we adapt and improve the analytic schema used to evaluate the water security of urban supplies- the result of previous studies - for the case of the Guandu System/RJMR. Finally, we apply this schema based on a literature review and official documents, complemented by interviews.

\section{Water and Climate Change}

Climate change and its potential impacts on natural resources have been subject to systematic studies, notably after the creation of the Intergovernmental Panel on Climate Change (IPCC) in 1988 and the publication of its reports for 2001, 2007 and 2014. Today there is little doubt that climate change is manifesting in diverse forms under the influence of human actions, especially global warming, the greater frequency and intensity of extreme events, changes to rainfall patterns, disturbances to ocean currents, glacial retreat and rising sea levels.

Researchers have emphasized that water cycles will be strongly affected by climate change (IPCC, 2007 and 2014; BATES et al., 2008; MMA, 2016; ANA, 2016). For Conway (2013), the uncertainty is particularly high in terms of future rainfall patterns with potential fluctuations in precipitation over the next decades, leading to wet and dry periods in the same location. This uncertainty has strongly influenced the research and the practical approaches to adaptation in the water sector, since it breaks a basic paradigm of water management: reliance on past observations to project current and future conditions. Though highly uncertain, the effects of climate change will impact on all dimensions of water security, above all the increased frequency and intensity of floods and droughts. In regions facing reduced rainfall, the expectation is for the quality of water sources to worsen during severely dry periods and droughts.

In sum, the risks related to public water supply — associated with extremes of excess and scarcity - are expected to increase significantly. In metropolitan regions, these will affect systems and populations already highly vulnerable due to other stressors, such as the increase in water demand arising from the demographic and economic growth of the metropolises, poverty, and unchecked urban sprawl, which suppress ecosystems and reduce resilience.

In Brazil over the last decade, many initiatives and studies have focused on the impacts of climate change. Nevertheless, important gaps remain in the information on climate change and water resources, as pointed out by ANA (2016) and by the National Plan for Adaptation to Climate Change (MMA, 2016). These reports highlight the need for studies in climate projections and their impacts on water availability, emphasizing the uncertainty surrounding the phenomenon of stationarity, given that hydrological series show upward and downward trends that have not so far been considered. 


\section{Climate change in the context of RJMR policies and plans}

Climate change became a public policy theme for the Rio de Janeiro Metropolitan Region (RJMR) from 2010, when the law was approved setting out the State Policy for Climate Change (Law 5690/2010 and Decree 43.216/2011). However, this legal framework was extremely generic in terms of water. It merely indicated an expansion from 40 to 400 linear $\mathrm{km}$ of projects and works along river banks until 2030, in order to minimize the impacts of intense rainfall and environmentally regenerate areas subject to unplanned urban growth. However, the issue of water security is not addressed. In other words, public policy for climate change, due to its incipient and incomplete nature, offers few instruments for responding to the question of water and its management under pressure of climate stressors.

Other planning instruments - the State Plan for Water Resources (PERHI, 2014) and the study by the Federation of Industries (FIRJAN, 2015) - focus on water security in general, but do not connect the issue to climate change. Meanwhile the Water Security National Plan (ANA, 2019) approaches the water security of the RJMR from the viewpoint of infrastructure.

For the purposes of the present study, the most important planning document is the Strategic Plan for the Integrated Urban Development of the Rio de Janeiro Metropolitan Region (PDUI, 2018), set out in State Law 5.192/2008 in response to the requirements of the Statute of the Metropolis. Despite the existence of prior studies (the 'Mega-Cities Vulnerability and Climate Change' project elaborated by INPE-Unicamp/NEPO, 2011), the PDUI does not explore the theme of climate change in depth: it only mentions the need to adapt the existing infrastructure and increase the resilience of the metropolis's urban structures, as detailed later in this paper.

\section{Water security: concepts and analytic schema}

Cook and Bakker (2012) and Melo (2016) observe that the expression 'water security' reflect the different understandings and/or approaches of diverse disciplines and actors - academia, multilateral bodies, water managers, public authorities and civil society. The authors emphasize how the concept has widened over time, initially focused on the quantity of water for human use and later expanded to include questions of quality, public health and ecological concerns. As a concept, it can also be explored at different scales: municipal/local/community; regional, hydrographic basin; state or provincial levels; national; and supranational.

The conceptual dynamism of research on water security is also observed by Jepson et al. (2017). They point to the large number of articles and books emphasizing questions of risk, rights, sustainability and environmental adaptation, water quality and complexity, despite the predominance of the definition of water security in terms of the excess or scarcity of water resources.

The authors themselves expand on the concept by encompassing the human right to water, including the availability, quantity, quality and economic accessibility of public 
water supplies. Such rights are included in the SDGs, which came to be seen as key parameters for evaluating water security (JEPSON et al. 2017). This concept is in line with the concept developed by Empinotti, Cortez and Ferrara (2020), who argue that universal access to water must be one of the basic premises of water security, and that without universalization, people live under constant water insecurity, thus undermining a basic human right.

Along the same lines, the present article is interested in the water security of the human supply of the RJMR from end to end, thus encompassing two main dimensions, as defined by Melo (2016): (i) the guarantee of water resources security in terms of quantity and quality, which is localized in the hydrographic region upstream of the intake point, and is the responsibility of the water resource management body, in coordination with the environmental management system and other correlate policies; and (ii) the drinking water supply to the population, which is generally the task of the municipalities and their contracted service providers. In the event of failure of any part of the water supply network - namely withdrawal, treatment, storage and distribution - a significant decline may occur in the water security to end consumers.

Figure 2 proposes an analytic schema involving the two dimensions of water security, which will guide the qualitative analysis of the current level of water security to the metropolitan west of Rio de Janeiro in the following two items of this paper. 
Figure 2 - Analytic schema for the qualitative analysis of water security of the public supply to the RJMR by the Guandu System.

Water Resources Management

Water Supply System

Paraíba do Sul River Basin - Guandu River Basin

Guandu System

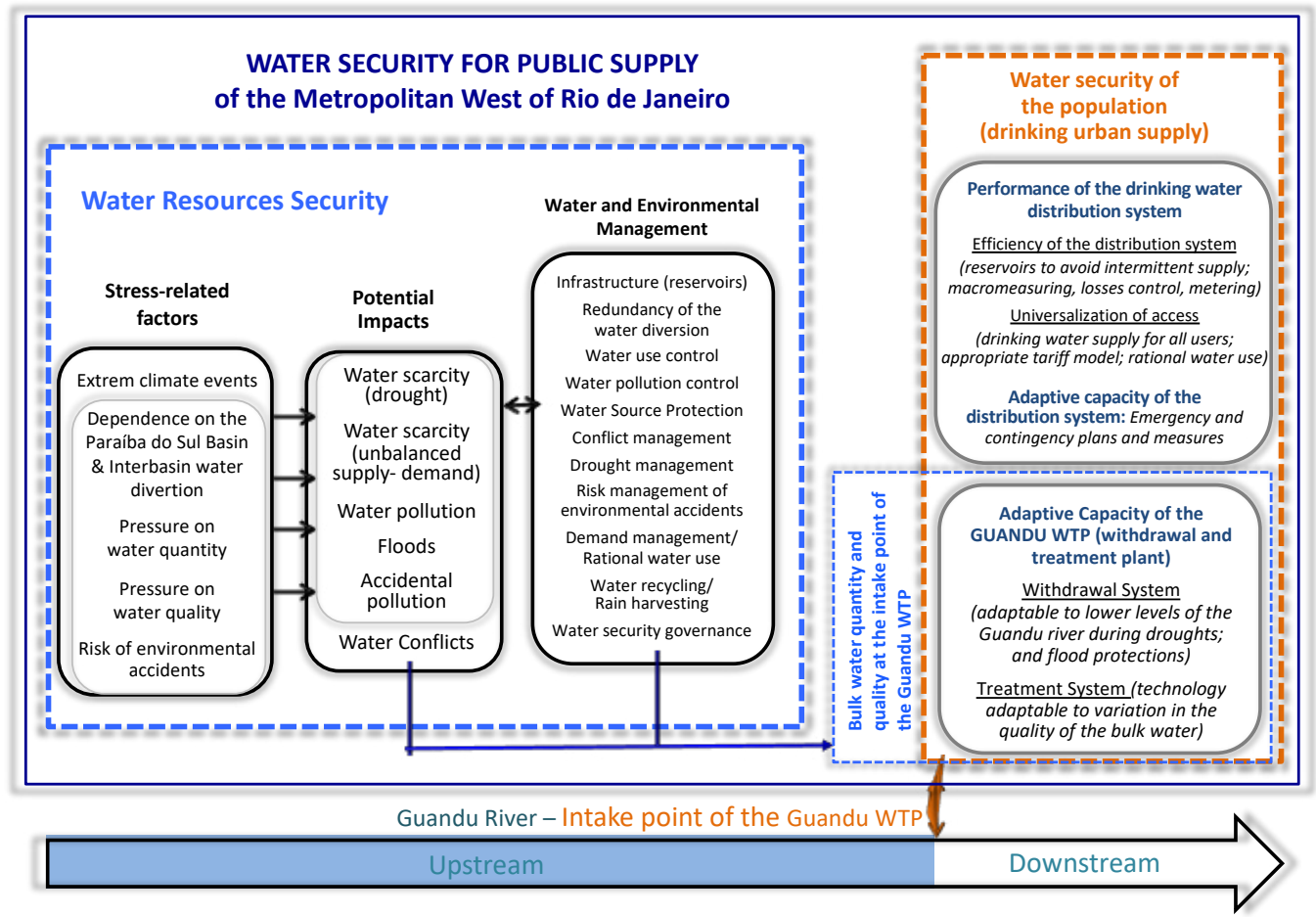

Source: Adapted from Formiga-Johnsson and Melo (2016) and Nogueira (2011).

\section{Water security associated with water resources - Guandu System}

Inspired by Nogueira (2011), the stress factors were taken as the axis of the evaluation, highlighted in Figure 2 above. These were associated with the impacts on the water resources that are used by the Guandu WTP, as well as the management actions taken in response to the stressors/impacts.

Dependence on the Paraíba do Sul river basin $\mathcal{E}$ interbasin water transfer infrastructure

Official documents concur that the most critical vulnerability of the RJMR water supply is its profound dependence on the waters of the Paraíba do Sul river basin (PERHI, 2014; PDUI, 2018; ANA, 2019). The reliance on a single source reduces the response capacity in the case of failure (PDUI, 2018). As pointed out by PERHI (2014), 83\% of the metropolitan population, or 9.4 million people, are supplied by the Guandu/Lajes/ 
Acari Systems.

The most important of these three systems is the Guandu System which depends exclusively on the diverted waters from the neighbouring basin of Paraíba do Sul, through the so-called 'Paraíba do Sul-Guandu Hydraulic System.' The latter is formed by a complex set of rivers, reservoirs, hydroelectric plants other hydraulic structures that involve the upper and middle parts of the Paraíba do Sul river basin, as well as the Guandu river basin via the water transfer that interconnects the two basins at the site of the Santa Cecília Pumping Station on the Paraíba do Sul river.

Initially designed to generate electricity, the inter basin water transfer is today more important for supplying the RJMR and many industries in the Guandu basin. The Guandu Water Treatment Plant (WTP) withdraws around $42 \mathrm{~m}^{3} / \mathrm{s}$ continuously and is currently being expanded to treat another $12 \mathrm{~m}^{3} / \mathrm{s}$. CEDAE, the Rio company that operates the WTP and the Guandu System, also has an additional $12 \mathrm{~m}^{3} / \mathrm{s}$ as a future water reserve, totalling $24 \mathrm{~m}^{3} / \mathrm{s}$ of water reserve. In other words, the dependence on the Paraíba do Sul river basin will become even more pronounced.

For this reason, another aspect highly relevant to the water security of the RJMR is the interbasin water infrastructure, operated by Light, which forms part of the Paraíba do Sul-Guandu Hydraulic System. Today part of this infrastructure is vulnerable because it did not receive adequate preventive maintenance since 1978. As lengthy maintenance works require paralysation of the diversion, these have become unviable due to the high dependence of the metropolitan supply.

This question was discussed at length in 2010, when a risk mitigation study produced by Light (2010, apud NOGUEIRA, 2011) identified the need to construct a redundancy system for the diversion, advocated too by all subsequent plans (PERHI, 2014; GUANDU PLAN, 2018; PDUI, 2018; and ANA, 2019). Up to now, the inter basin transfer infrastructure has not failed and has proven capable of guaranteeing water resources to the Guandu WTP, but a solution is urgently needed.

\section{Pressure on water quantity}

According to the State Plan for Water Resources (PERHI, 2014), the current volume $\left(45 \mathrm{~m}^{3} / \mathrm{s}\right)$ and the two water reserves $\left(12 \mathrm{~m}^{3} / \mathrm{s} \mathrm{each}\right)$ of CEDAE for the Guandu WTP provide more water than the amount needed to universalize access to current and future population of the metropolitan west of Rio de Janeiro. This projection takes into account a population increase until its stabilization in 2047, even in the 'business-as-usual scenario' with little or no rational use of water.

In terms of water availability in quantity, therefore, in normal water years, an apparent comfort and security can be observed. However, our study provided evidence of a huge potential vulnerability associated with stress factors on the waters of the Paraíba do Sul river basin.

First, as a result of the growing demand for water in the Paraíba do Sul river basin, 
the minimum flow from the Paraíba do Sul river to the Guandu basin has decreased, dropping from $160 \mathrm{~m}^{3} / \mathrm{s}$ to $119 \mathrm{~m}^{3} / \mathrm{s}$ (COSTA et al., 2015).

Second, the water diversion to the Guandu has increasingly become subject to polemical debates, involving the Paraíba do Sul river basin in São Paulo and also in Rio de Janeiro state (Records of the Meetings of the Working Group for Monitoring the Hydraulic Operation in the Paraíba do Sul River Basin - GTAOH/CEIVAP, between 2014 and 2019). ${ }^{1}$ Various factors could set off future conflicts that could result in proposals to reduce the current amount of water diverted to the Guandu: increased demand for water in the Paraíba do Sul basin itself, reduced water availability provoked by climate change, or an increase in the second inter basin water transfer to São Paulo, which became a federal conflict between the states of São Paulo and Rio de Janeiro (FORMIGA-JOHNSSON et al., 2015).

In sum, while in normal water years the situation can be defined as relatively comfortable, the recent droughts - the next topic we address - have shown that the Paraíba do Sul river basin is vulnerable in moments of extreme hydrological events, a phenomenon that was not observed before the end of the 1990s. Hence, the management system needs to be more efficient in order to control water uses, stimulate rational use and, above all, establish pacts for water allocation in the Paraíba do Sul basin between the states of São Paulo, Rio de Janeiro and Minas Gerais, under the coordination of ANA, including the diversion to the Guandu during times of hydrological extremes.

\section{Extreme climate events}

Available studies on the historical precipitation in the Paraíba do Sul and Guandu river basins present conflicting findings. Nobre and Marengo (2017), for example, provide evidence of an increase in rainfall and flows in the Southeast and South of Brazil over the last 50 years, while the Guandu Plan (2018) points out that the total annual rainfall volumes in the Guandu basin have declined over the same period.

An important indicator in terms of the impacts of extreme climate events in these basins are the severe droughts of 2001-2003 and 2014-2015. Nauditt et al. (2019) show the exceptionality of the drought in these periods, especially in 2014-2015, observing a strong flow anomaly observed at the Paraíba do Sul fluviometric station, located in the upstream area of the Guandu WTP. This showed a permanent shortfall $(<0)$ during these drought periods when compared to the 1935-2016 reference period at all time scales of the Standard Discharge Index (SDI). Figure 3 highlights the drought periods that occurred over the last 30 years.

1. Available at http://www.ceivap.org.br/ophidraulica.php. 
Figure 3 - Values of the Standard Discharge Index (SDI) at all monthly time scales for the Paraíba do Sul fluviometric station between 1935 and 2016.*

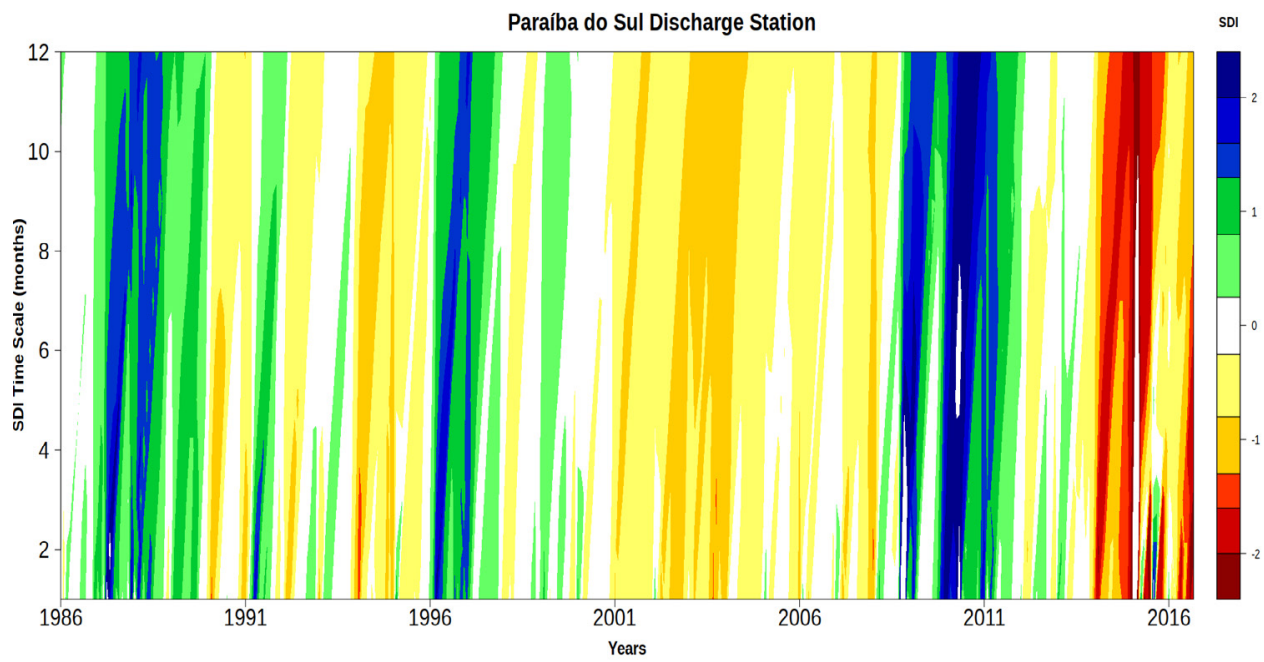

* In yellow: more severe dry periods; in red, hydrological drought anomalies.

Source: Nauditt et al., 2019.

Associated with non-climate stressors, the severe drought of 2014-2015 substantially affected the water avail ability in the Paraíba do Sul basin, and consequently in the Guandu river, thus forcing the already complex water management in these basins to be more adaptive.

In response, the Committee for the Integration of the Paraíba do Sul River Basin (CEIVAP) reactivated the Working Group for Monitoring the Hydraulic Operation in the Paraíba do Sul River Basin (GTAOH), which had been set up in conjunction with ANA and the Guandu Committee during the 2003 drought. During the crisis, GTAOH sought adaptive solutions from water users that enabled the saving of water stored in the reservoirs for use in the case of prolonged drought, as actually happened. There was considerable concern over the public supply, especially within the RJMR, which was hosting international sporting events (the FIFA World Cup in 2014, and the Olympics and Paralympics in 2016).

The first measure proposed was to gradually reduce the flow of the Paraíba do Sul river, as well as the diversion to the Guandu river. Over 2014 and 2015, the water diverted was gradually reduced from $119 \mathrm{~m}^{3} / \mathrm{s}$ to $75 \mathrm{~m}^{3} / \mathrm{s}$ (ANA Resolutions from 2014 to 2016), ,a reduction unparalleled since the construction of the 'Paraíba do Sul-Guandu Hydraulic System' at the beginning of the 1950s.

This scale of significant flow reduction was only possible with subsequent impacts

2. Available at http://ceivap.org.br/resolucoes-ana.php. 
on diverse water users (COSTA et al., 2015; VASCONCELOS, 2019). Specifically, the Guandu WTP was exposed to a situation of technical stress never previously experienced, making successive adaptations to the withdrawal and treatment systems necessary. The worsening quality of the water entailed a $20 \%$ increase in the use of chemical products by the treatment system, an additional 52 tons/day (VASCONCELOS; FORMIGAJOHNSSON e RIBEIRO, 2019).

With these adaptations and the collective real-time management of the levels of the Paraíba do Sul and Guandu rivers, the Guandu WTP managed to operate continuously, maintaining its production at usual flow. The population of the RJMR supplied by the Guandu System was not affected at any moment. The water crisis was declared to be over only at the end of 2016.

Despite the greater frequency of droughts, until March 2020, the basins of the Paraíba do Sul and Guandu rivers still lacked any water security or operational plans for critical moments of drought.

\section{Pressure on water quality}

The quantity of chemical products used by the Guandu WTP (260tons/day) is one indicator of its vulnerability due to the problems relating to the quality of the water resources. The main source of pollution are the Poços, Queimados and Ipiranga rivers, tributaries of the Guandu river that are located immediately upstream of the water intake point (PERHI, 2014; GUANDU PLAN, 2018; PDUI, 2018; and ANA, 2019). These rivers receive a large influx of domestic and industrial effluents, making them heavily polluted and sometimes provoking eutrophication and the blooming of cyanobacteria.

This is why despite using only $38 \%$ of the diverted flow from Paraíba do Sul basin $\left(119 \mathrm{~m}^{3} / \mathrm{sin}\right.$ normal water times), a much higher flow is needed in the Guandu river in order to dilute the pollution and make the bulk water 'treatable' by the Guandu WTP. During the 2014-2016 water crisis, when the Guandu river flow reached the minimum of $75 \mathrm{~m}^{3} / \mathrm{s}$ (rather than at least $120 \mathrm{~m}^{3} / \mathrm{s}$ ), the WTP demonstrated an unparalleled adaptive capacity despite increasing the volume of chemical products (VASCONCELOS, 2019).

It was surprising, therefore, that a serious crisis in the quality of the drinking water distributed by the Guandu System occurred in January 2020, precisely during the rainy season and the larger flow of the rivers. The occurrence of geosmin was associated with the water pollution problems at the intake point, as mentioned above, and provoked a bad smell and earthy taste in the drinking water from the Guandu System. This led to high insecurity for millions of people in the Rio de Janeiro metropolis, worsened by communication problems on the part of CEDAE and the Rio de Janeiro State Government (FIOCRUZ, 2020; GAEMA/MPRJ, 2020).

A palliative solution to this problem has been discussed for almost 30 years and has been proposed by official sources (CEDAE, 2014, quoted in PERHI, 2014; PDUI, 2018; PNSH, 2019): a project to divert the polluted tributaries in to the downstream part of the Guandu river in order to protect the WTP in take point. This, though, is a 
highly controversial project since many argue for a definitive solution instead: namely, controlling pollution in the Poços, Queimados and Ipiranga river basins, as foreseen in the official plans, though these require more execution time and higher levels of investment.

In an official statement published on February 10, 2020, FIOCRUZ emphasized that the recent problems confirm that the "pressures on the water quality of the Guandu river are not momentary or sporadic $[. .$.$] and that the future recurrence of events simi-$ lar to the present should be expected, set to be exacerbated by the climate change and variability" (FIOCRUZ, 2020).

Given the seriousness of the events at the beginning of 2020, we consider the pollution of the water resources at the intake point- which was already a significant stressor - as the main stress factor on the Guandu WTP.

\section{Risk of environmental accidents}

The risk of environmental accidents relating to the Guandu WTP covers a broad territorial area due to the inter basin water transfer: the entire hydrographic region upstream of the intake point, which includes the upper portion of the Guandu basin and the entire Paraíba do Sul basin upstream of the diversion.

The risk of accidents is particularly high in the more industrialized areas of the Paraíba do Sul basin (fixed sources), in the São Paulo section and the middle course of the Paraíba do Sul in Rio de Janeiro state, as well as along the extensive network of railways and highways (mobile sources) close to the watercourses in the two basins (VIANA; FORMIGA-JOHNSSON; STRAUCH, 2012; GUANDU CBH, 2015). An emblematic example was the spillage of the insecticide Endosulfan into an affluent of the Paraíba do Sul river by the company Servatis, on the Middle Paraíba do Sul, in 2008. The diversion was interrupted to avoid polluting the Guandu river and interrupting the withdrawal of the Guandu WTP, as also occurred in the municipalities located along the course of the Paraíba do Sul river.

The Guandu Committee elaborated a water supply contingency plan (GUANDU $\mathrm{CBH}, 2015)$ by identifying the potential sources of accidental pollution, detailing the Guandu basin, listing those involved and their responsibilities in the case of technological environmental accidents. This plan confirms the conclusions of Viana, Formiga-Johnsson and Strauch (2012): despite the withdrawal from the Guandu WTP presenting relative vulnerability in relation to environmental accidents from fixed and mobile sources, no record was identified of complete paralysation of the Guandu WTP due to environmental accidents. When accidents occur in the Paraíba do Sul basin, the interbasin water transfer serves to protect the metropolitan supply, since it can be interrupted so as not to contaminate the Guandu river.

Finally, we did not identify a more robust policy for preventing and reducing accidents by fixed and mobile sources able to affect the Guandu WTP, even after the elaboration of the contingency plan by the Guandu Committee. 
Water security at the end point: access to drinking water in the municipalities supplied by the Guandu System

\section{Universalization of access}

The data from the 2017 SNIS shows that among the municipalities served by the Guandu System, only Nilópolis, Mesquita, Rio de Janeiro, Nova Iguaçu and São João de Meriti present percentages over $90 \%$ of drinking water supply. Two municipalities were located in the $80.1 \%$ to $90 \%$ band: Duque de Caxias and Queimados. Meanwhile, in the band immediately below, $60.1 \%$ to $80 \%$, were the municipalities of Belford Roxo and Japeri.

Even municipalities with more than $90 \%$ of households connected to the public water supply show an intermittent service (PDUI, 2018). The latter plan indicates that in Nova Iguaçu and São João de Meriti, for example, there are problems related to the irregular frequency of the supply, the lack of pressure in the network, and the low quality of the drinking water supply that have forced residents to seek palliative solutions, such as wells, to compensate for the failures in the mains water system.

According to Quintslr (2018), in the Baixada Fluminense region in general and Duque de Caxias in particular, in some households residents themselves disconnected from the water network due to the simple fact that they were not receiving any water in their homes. Even so, many reported that they continued to receive water bills based on estimated consumption (QUINTSLR, 2018). In sum, the RJMR and especially the metropolitan west served by the Guandu System do not have universalized services, which reduces water security and makes users more vulnerable to potentially drought situations arising from a context of climate change.

Among the Metropolitan Objectives of the PDUI (2018), which guide the Priority Action Programs, Objective 11 includes the need to improve the drinking water supply and sewage systems, aiming towards their universalization.

\section{Performance of the treated water distribution system}

The Baixada Fluminense region, almost entirely served by the Guandu System, is characterized by incomplete systems in terms of both pipelines and reservoirs: the system's end-point reservoirs (at the end of the Baixada pipeline) do not function and the water fails to arrive due to a lack of pressure. This generates a situation of permanent water insecurity, irrespective of the availability of water resources.

The problem dates to the 1990s. The Plan for Sectorization of the Baixada Fluminense Water Supply was developed during the Moreira Franco government (1987-1991), under the responsibility of the Urban Development Office (SEDUR) and CEDAE. The plan's objective was to "divide the region into 48 areas of influence and create its own supply system with a water reservoir for each area and a sub-pipeline linking the region 
to the nearest pipeline" (SEDUR, $\mathrm{n} / \mathrm{d}$ ). Around 3,400 $\mathrm{km}$ of pipes would be laid in the Baixada Fluminense region -including sub-pipes and distribution pipes networks - accompanied by the construction of 31 new water reservoirs, as well as the renovation of other existing reservoirs. Only the first phase of the project was developed, implanting 89 $\mathrm{km}$ of pipelines in the municipalities of Nova Iguaçu $(61 \mathrm{~km})$, Nilópolis $(9 \mathrm{~km})$, Duque de Caxias $(15 \mathrm{~km})$ and São João de Meriti $(4 \mathrm{~km})$. No reservoirs were built in this first phase (PORTO, 2003).

The 1990s saw new programs designed to solve the water supply issue. Here we can pick out the Guanabara Bay Depollution Program (PDBG), whose objectives included balancing the supply and demand of water in the Baixada Fluminense. The program set out from the observation of the precarious functioning of the water supply system since there was no physical separation between adduction and distribution: in other words, there were no reservoirs or sectorization of the distribution system. This provoked a lack of water or irregular distribution at diverse points, and excessive pressure at others, causing an increase in leaks, pipe damage and general wastage.

As part of the PDBG, therefore, to improve supply in the Baixada Fluminense region, three reservoirs were built in Duque de Caxias, two in São João de Meriti and three in Belford Roxo, Also in these municipalities, the installation of sub-pipes, distribution networks and household connections was planned, works that were never concluded. The result of this set of unfinished works are reservoirs left empty or operating well below their capacity.

In 2018, through its 'Inhabiting the Metropolis' program, the PDUI prioritized an expansion in access to drinking water, particularly in the Baixada Fluminense region, and an increase in the operational security of the water supply system for the western region of the RJMR. To this end, it was planned to carry out studies and projects and implement works necessary for the smooth operation of the Guandu System and other isolated water supply systems in its region of coverage, including the continuation and complementation of works already planned (PDUI, 2018).

The situation of water insecurity in the metropolis also encompasses another dimension: water losses in the Guandu System. Loss of water is considered one of the main indicators of operational performance of the public service providers for the water supply. They occur in all components of a water supply system from withdrawal to distribution. The magnitude of these losses depends on each unit and involves: (i) real or physical losses: all the water that leaks within the system, except in the installations of users, arising from ruptured pipes and structural cracks and fissures in the impermeabilizations of reservoirs; (ii) apparent or non-physical losses: all water that is unmeasured or used in undefined fashion, arising from clandestine and/or irregular connections, absent hydrometers or fraudulent readings, micro measuring and macro measuring errors, record errors, reading errors and so on.

Observing the municipalities covered by the Guandu System/CEDAE, a fairly high level of non-physical losses can be identified. In addition to clandestine connections, the causes may be the lower number of hydrometers in municipalities with a high number of 
connections like those of Baixada Fluminense. SNIS 2017 depicts this situation (Figure 4).

Figure 4: Measurement, metering and losses in the municipalities covered by the Guandu System in 2017

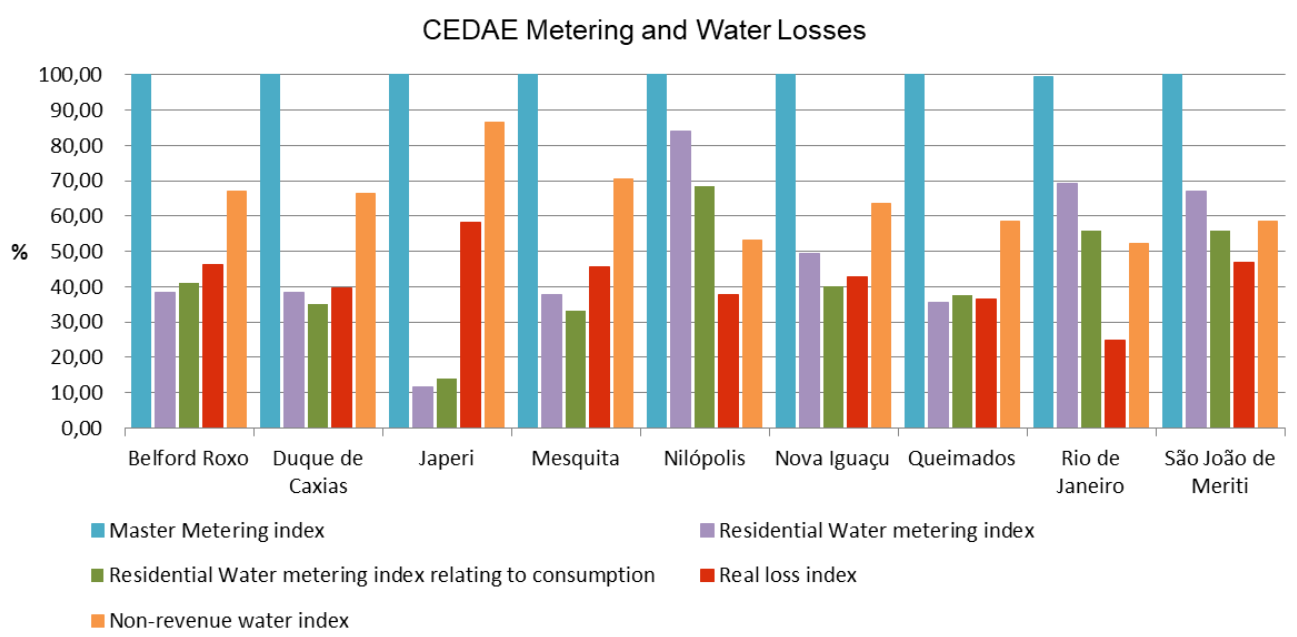

Source: Based on data from SNIS, 2019.

For the Brazilian Southeast, the National Plan for Basic Sanitation - PLANSAB (2013) set as a target a reduction in the level of distribution losses (physical losses) to at least 33\% by 2018. A distribution network without losses is not a viable objective in technical terms, meaning that there is a limit to its potential reduction. The data from the SNIS, provided by CEDAE, show that only in Rio de Janeiro municipality losses were lower than the target set by PLANSAB. At the opposite extreme, Japeri has the highest rate of losses, over $50 \%$, a fairly critical amount.

Physical losses have a direct implication for water availability and affect the supply system as a whole: the higher the loss, the more water will be required from the supply sources for subsequent treatment and distribution, thus requiring more investments and expenses on exploration. In the Guandu System, a significant portion of the volume of treated water does not reach homes due to leaks in the adduction pipelines, in the distribution networks and in the reservoirs, or to irregular connections to the main pipelines.

As part of the PDUI (2018) 'Sustainable Metropolis' program, the creation of a program to reduce physical losses in the water network is suggested. Its main actions are: (i) research non-visible leaks with the use of electronic geophones and/or noise correlation equipment, for example; (ii) the implantation of devices like pressure control valves and reservoirs to reduce excessive pressure in the supply network; (iii) there placement of deteriorating pipes in the supply and main pipeline networks (PDUI, 2018). In addition, a public awareness program is proposed and incentives for the sustainable use of water with a reduction in consumption. However, it is paradoxical to speak of reducing 
consumption in a generic form in a context of non-universalized services.

Figure 4 above also reveals that many municipalities have a low percentage of water connections fitted with hydrometers. This means that water billing is based on estimated consumption. Users have no control over their consumption, nor any guarantee that they are paying the right amount. Furthermore, as verified by the PDUI, many areas suffer from intermittent supplies, but even if the water does not enter the homes every day, the bill arrives at the end of the month with the amount based on estimated consumption. Clearly this encourages defaults in payment.

The PDUI contains proposals in its 'Inhabiting the Metropolis' program for an initiative called 'Rationalization of the use of drinking water through a broad program of public awareness and participation.' This aims to: (i) support the large-scale implementation of individual hydrometers, generating increased control over consumption and raising public awareness about economizing drinking water; (ii) support the review billing in the water supply sector with increased tariff penalties for high consumption, encouraging rational use of water; and(iii) stimulate the creation of digital platforms for the population in which the public can participate in improving the supply systems by indicating the locations where leaks and losses from the water supply networks occur. The initiative emphasizes that investing in demand management is just as important as investment in supply (PDUI, 2018).

CEDAE is making high levels of investments to increase the quantity of water available in the Baixada region through a program called 'New Guandu, More Water for Baixada.' The project resources derive from a loan from Caixa Econômica Federal. The works involve the expansion of the Guandu production system with the duplication of the Guandu WTP, the expansion of the main pipeline with the construction of the New Baixada Pipeline; the construction/reform of 17 reservoirs and the laying of distributor feeder channel sand supply networks.

The new WTP, with the capacity to produce $12 \mathrm{~m}^{3} / \mathrm{s}$ of drinking water, will count on CEDAE's largest reservoir (Marapicu II), with a capacity to store 55 million litres of water, to supply Nova Iguaçu, Duque de Caxias, Belford Roxo, Mesquita, Nilópolis, São João de Meriti and Rio de Janeiro. This phase of the project aims to increase the supply of water to the Baixada Fluminense and to provide greater security for the existing treated water production system, serving as an alternative in risk situations and whenever maintenance is necessary. Although the works are important to ensuring water security, if there is no control of losses through the monitoring of pipelines to avoid leaks and irregular connections and through the expansion of micro measuring, the some of these investments will be undermined.

It is worth recalling that CEDAE does not possess a social tariff model that considers low-income residents living in formal areas, like a large proportion of the Baixada region's population. This explains the high level of defaults on payment and the recourse to alternative solutions like wells. Presuming that these residents possess hydrometers, the availability of a minimum free volume and social tariffs matching the capacity to pay could help reduce the losses in household connections. Likewise, hydrometers should 
be adopted in all commercial establishments with measurements and billing. Many establishments in the Baixada region have irregular connections and thus pay nothing for the water they consume.

Finally, adoption of a management system oriented towards water security, considering the performance of the distribution system for treated water, includes CEDAE's adoption of two programs that do not figure in its reports: the control of losses, guided by sustainable management; and the demand management program, which preserves the rights of users to receive water every day in their houses at a fair price, in accordance with their consumption and their economic-financial capacity, thus respecting the principles linked to the human right to water.

\section{Planning in situations of failure of the distribution system}

Another aspect to be considered is the adaptive capacity of the distribution system, including emergency preparedness and contingency plans, which set out what to do in the case of a partial or localized lack of drinking water. These a real so guided by the need to protect the population's health as advocated by FIOCRUZ (2020). Lack of water may have originated from contamination of the water source, water scarcity, flooding damage to the intake infrastructure, prolonged interruption to the electricity supply in the production facilities, or other operational problems. In CEDAE's public documents, we did not identify any water security measures for the population in emergency situations, which reveals another element of vulnerability in the management of the drinking water supply services.

\section{Conclusions}

Understanding that building water security is also related to the capacity of the Rio de Janeiro metropolis to face the negative scenarios related to climate change and ensure safe water supply to the population, we have identified various problems related both to the availability of water resources and to the access to drinking water.

With regard to water resources, an increasing vulnerability was observed as a result of extreme dry periods, which provoked a water crisis without precedent in 2014-2016 and drought came to be considered a new management problem in the Paraíba do Sul and Guandu basins. However, the adaptive capacity of the water management system, associated with adaptations of the Guandu WTP's withdrawal and treatment system, avoided any problem related to the drought and provided water security for the metropolitan population during the water crisis.

It was also shown that, currently, the non-climate stressors that most affect or may affect the quantity and quality of the water resources at the intake point by the Guandu System are generally associated with problems of urbanization, land use and occupation, planning and management. In order of importance, these are: water pollution at the intake point of the Guandu WTP, which reflect the serious environmental problems of the 
water sources; the deep dependence on the Paraíba do Sul river basin and the increase in demand and conflicts surrounding its waters, such as the Rio-São Paulo conflict in 2014-2015; the lack of maintenance of the water diversion infrastructure to the Guandu river; and the risks of environmental accidents.

Looking to the future, the two reserves of water availability guarantee - legally the quantity of water needed to supply the entire metropolitan west, but this apparent security is threatened by various stressors identified in this study.

Despite the many risks related to water resources, it was possible to conclude that the factor that most jeopardizes the current water security of the population in the metropolitan west of Rio de Janeiro is the performance of the drinking water supply service, since the availability of water resources is not an impediment to universalizing access or to improving the quality of the provided service. There are approximately 587,000 people without access to the water supply network as a result of the unequal expansion of the urban infrastructure, as well as a significant number of users connected to the public network but without regular access to drinking water. This situation reflects the socioeconomic inequality of Brazilian society, or its hydrosocial scarcity to use the concept of Swyngedouw (2009), which has become strongly evident during the COVID-19 pandemic: it is precisely the most vulnerable section of the population, who lack access to safe water for their personal and household hygiene, that is the most affected (EMPINOTTI; CORTEZ; FERRARA, 2020).

In sum, global water security, which can make the Rio de Janeiro metropolis less vulnerable to future climate extremes, depends on more efficient and proactive management of water resources, in the sense of anticipating the problems already described, and, above all, improving the performance of the drinking water supply service so that it is more inclusive and more efficient. This proactiveness can occur - in addition to expansion of the distribution network - through a gradual reduction of losses, increased stimulus to the water reuse by the industrial sector and by some urban services, and the implementation of rainwater harvesting systems for non-potable uses. These measures are consistent with the sustainable management needed to meet SDG 6, and could reinforce the resilience, capacity for adaptation and full water security of the population supplied by the Guandu System.

\section{ACKNOWLEDGEMENTS}

The research for this paper was financially supported by CNPq, FAPERJ, UERJ (Prociência Program) and Comitê Guandu/AGEVAP. We thank David Rodgers for translating this article into English. 


\section{References}

ANA. Atlas Brasil de Abastecimento Urbano. Brasília: ANA, 2010.

ANA. Mudanças Climáticas e Recursos Hídricos: avaliações e diretrizes para adaptação. Brasília: ANA e GGE, 2016.

ANA. Plano Nacional de Segurança Hídrica - PNSH. Brasília: ANA, 2019.

BATES, B.C et al. (Coord.). Technical Paper. Climate Change and Water. Geneva: IPCC Secretariat, 2008.

BRASIL. Ministério das Cidades. Plano Nacional de Saneamento Básico - PLANSAB. Brasília: Ministério das Cidades, 2014.

BRASIL. Ministério das Cidades. Sistema Nacional de Informação sobre Saneamento: Diagnóstico dos serviços de Água e Esgoto - 2017. Brasília: Ministério das Cidades, 2019.

BRITTO, A. L.; FORMIGA-JOHNSSON, R. M.;CARNEIRO, P. R. F. Abastecimento público e escassez hidrossocial na Metrópole do Rio de Janeiro. Ambiente $\mathbb{\&}$ Sociedade, v. 19, n. 1, p. 183-206, 2016.

CBH GUANDU. Relatório final. Plano de contingência para abastecimento de água (Guandu). Londrina: DRZ Gestão e Consultoria, 2015.

CONWAY, D. Water Security in a Changing Climate. In: Lankford, B. et al. (Coord.). Water Security: Principles, Perspectives and Practices. London, Routledge, 2013. p. 80-100.

COOK, C.; BAKKER, K. Water security: Debating an emerging paradigm. GlobalEnvironmental Change, v. 22, n. 1, p. 94-102, 2012.

COSTA, L. F; FARIAS JUNIOR, J. E. F; FORMIGA-JOHNSSON, R. M.; ACSERALD, M. V. Crise hídrica na Bacia do rio Paraíba do Sul: enfrentando a pior estiagem dos últimos 85 anos. Revista Ineana, v. 3, n. 1, p. 26-47, 2015.

EMPINOTTI, V.; R CORTEZ, R. S.; FERRARA, L. N. Coronavírus e segurança hídrica: é preciso acesso universal à água. Carta Capital, 10 de abril de 2020.

FIOCRUZ. Conselho Deliberativo da Fiocruz divulga nota sobre a qualidade da água no Rio de Janeiro. Rio de Janeiro, 10 de fevereiro de 2020, disponível em https://portal.fiocruz.br/ print/77059.

FIRJAN. Relatório Final. Avaliação da segurança hídrica da Região Metropolitana do Rio de Janeiro. Rio de Janeiro, 2015. 
FORMIGA-JOHNSSON, R. M; LEMOS, M. C.; SOUZA FILHO, F. Segurança hídrica e capacidade adaptativa urbana e metropolitana em tempos de mudanças climáticas. In: PHILLIPI JR, A.; SOBRAL, M.C. (Coord.). Gestão de bacias hidrográficas e sustentabilidade. São Paulo: Editora Manole, 2019. p. 427-459.

FORMIGA-JOHNSSON, R.M. et al. Segurança hídrica do Estado do Rio de Janeiro face à transposição paulista de águas da Bacia Paraíba do Sul: relato de um acordo federativo. Revista Ineana, v. 3, n. 1, p.48-69, dez. 2015.

GAEMA/MPRJ. Recomendação Ministerial. Ref: Procedimento Administrativo de Acompanhamento da ACP 0466729 13.2015.8.19.0001. Rio de Janeiro, 13 de janeiro de 2020.

IPCC.Working Group II, Climate Change 2001, 2007 e 2014: Impacts, Adaptation and Vulnerability.Cambridge: Cambridge University Press, 2001, 2007 e 2014.

JEPSON, W. et al. Advancing human capabilities f or water security: A relational approach. Water Security, n. 1, p. 46-52, 2017.

MELO, M.C. Segurança hídrica para abastecimento de áreas urbanas [...] 2016. Tese (Doutorado em Engenharia Civil). UFRJ/COPPE, Rio de Janeiro

MMA. Plano Nacional de Adaptação à Mudança do Clima. Vol. 2 [...]. Brasília: MMA, 2016.

NAUDITT et al. A grande seca de 2014-2015 na Bacia do rio Paraíba do Sul [...]. In: SOUZA-FILHO et al. (Coord.). ADAPTA - Gestão adaptativa do risco climático de seca. Fortaleza: Expressão Gráfica e Editora, 2019. p. 825-840.

NOBRE, C. A.; MARENGO, J. A. (Coord.). Mudanças climáticas em rede: um olhar interdisciplinar. São José dos Campos: INCT, 2017.

NOGUEIRA, M. A. R. B. Variabilidade climática, disponibilidade hídrica e ETA Guandu [...] 2011. Dissertação (Mestrado em Engenharia ambiental). UERJ, Rio de Janeiro.

PDUI. Plano Estratégico de Desenvolvimento Urbano Integrado da Região Metropolitana do Rio de Janeiro, Tomos I e II. Rio de Janeiro: Consórcio Quanta Jaime Lerner Arquitetos associados, Câmara Metropolitana, 2018.

PERHI. Plano Estadual de Recursos Hídricos do estado do Rio de Janeiro. Relatórios gerencial e síntese. Rio de Janeiro: Inea, Fundação Coppetec/UFRJ, 2014.

PLANO GUANDU. Plano Estratégico de Recursos Hídricos da Bacia Hidrográfica dos rios Guandu, da Guarda e Guandu Mirim. Relatório Gerencial. Rio de Janeiro: Comitê Guandu e Profill Engenharia e Ambiente, 2018.

PORTO, H. R. Saneamento e cidadania: trajetórias e efeitos [...] na Baixada Fluminense. Rio de Janeiro: FASE, 2003.

QUINTSLR, S. A (re)produção da desigualdade ambiental na Metrópole: [...] 2018. Tese 
(Doutorado em Planejamento Urbano e Regional) UFRJ, Rio de Janeiro.

VASCONCELOS, N. A.; FORMIGA-JOHNSSON, R. M.; RIBEIRO, N. B. Impactos da crise hídrica 2014-2016 sobre os usuários dos rios Paraíba do Sul e Guandu. REGA - Revista de Gestão de Água da América Latina, v. 16, e14, 2019.

VASCONCELOS, N. A. Impactos da crise hídrica 2014-2016 sobre os principais usuários [...] 2019. Dissertação (Mestrado em Engenharia ambiental). UERJ, Rio de Janeiro.

VIANA, V. J.; FORMIGA-JOHNSSON, R. M.; STRAUCH, C. E. Riscos ambientais envolvendo o transporte de produtos perigosos para as águas captadas pela ETA Guandu, RJ. Revista Ineana, v. 1, n. 1, p. 46-63, jan-jun, 2012. 
Rosa Maria Formiga-Johnsson

$\square$ rosa.formiga@eng.uerj.br

ORCiD: https://orcid.org/0000-0003-2047-9912
Submitted on: 16/10/2019

Accepted on: 08/06/2020

2020;23:e02071

\section{Ana Lucia Britto}

$\square$ ana.britto@fau.ufrj.br

ORCiD: https://orcid.org/0000-0001-6558-8405

How to cite: FORMIGA-JOHNSSON, R. M.; BRITTO, A. L. Water security, metropolitan supply and climate change: some considerations concerning the Rio de Janeiro case. Ambiente $\&$ Sociedade. São Paulo, v. 23, p. 1-22, 2020. 


\title{
Segurança hídrica, abastecimento metropolitano e mudanças climáticas: considerações sobre o caso do Rio de Janeiro
}

\author{
Rosa Maria Formiga-Johnsson \\ Ana Lucia Britto
}

São Paulo. Vol. 23, 2020

Tema em destaque:

Urbanização, Planejamento e Mudanças Climáticas
Resumo: Este trabalho avalia o nível atual de segurança hídrica da população da Metrópole do Rio de Janeiro abastecida pelo Sistema Guandu. Parte-se do pressuposto que a segurança hídrica é alcançada somente quando há universalização do acesso à água pela população, ou seja, quando há disponibilidade de água bruta, em quantidade e qualidade, e serviços de água que garantam o direito humano de água. Com base em pesquisas anteriores, revisão bibliográfica, documentos oficiais e entrevistas, foi possível adaptar e aplicar um esquema analítico de avaliação qualitativa de segurança hídrica ao Sistema Guandu. Conclui-se que são muitos os riscos associados à água bruta, incluindo estressores climáticos, mas é o desempenho do sistema de distribuição de água tratada que mais compromete a segurança hídrica atual da população do oeste metropolitano; a disponibilidade de água bruta, atual e futura, não é o impeditivo para a universalização do acesso à água.

Palavras-chave: Segurança hídrica; Abastecimento público; Mudanças climáticas; Sistema Guandu; Região Metropolitana do Rio de Janeiro.

Como citar: FORMIGA-JOHNSSON, R. M.; BRITTO, A. L. Segurança hídrica, abastecimento metropolitano e mudanças climáticas: considerações sobre o caso do Rio de Janeiro. Ambiente $\mathbb{\&}$ Sociedade. São Paulo, v. 23, p. 1-22, 2020. 


\title{
Seguridad hídrica, abastecimiento metropolitano y cambio climático: consideraciones en el caso de Río de Janeiro
}

\author{
Rosa Maria Formiga-Johnsson \\ Ana Lucia Britto
}

São Paulo. Vol. 23, 2020

Resumen: Este trabajo evalúa el nivel actual de seguridad hídrica para

Tema en Destaque:

Urbanización, Pla-

nificación y Cambio

Climático

la población de la metrópoli de Río de Janeiro abastecida por el Sistema Guandu. La seguridad del agua solo se logra cuando la población tiene acceso universal al agua: cuando hay agua cruda disponible, en cantidad y calidad, y servicios de agua que garantizan el derecho humano al agua potable. Basado en investigaciones previas, una revisión de la literatura y documentos oficiales, fue posible adaptar y aplicar un esquema analítico de evaluación cualitativa de la seguridad del agua al estudio de caso. Se concluye que existen muchos riesgos asociados con el agua cruda, incluidos los estresores climáticos, pero es el desempeño del sistema de distribución de agua tratada lo que más compromete la seguridad hídrica actual del oeste metropolitano; La disponibilidad de agua cruda, tanto actual como futura, no es un obstáculo para el acceso universal al agua.

Palabras-clave: Seguridad hídrica, Abastecimiento de agua potable, Cambio climático, Sistema Guandu, Región Metropolitana de Río de Janeiro.

Como citar: FORMIGA-JOHNSSON, R. M.; BRITTO, A. L. Seguridad hídrica, abastecimiento metropolitano y cambio climático: consideraciones em el caso de Río de Janeiro. Ambiente $\mathbb{\&}$ Sociedade. São Paulo, v. 23, p. 1-22, 2020. 